\title{
9
}

\section{When Food Crosses Borders: Paradigm Shifts in China's Food Sectors and Implications for Vietnam}

\author{
Hongzhou Zhang
}

\section{Introduction}

The paradigm shift of China's overall food security strategy as well as the Chinese consumers' growing anxiety over the safety and affordability of domestically produced food products have important implications for global food security and food markets beyond its borders, particularly its Southern neighbor-Vietnam. While Chinese agricultural presence in other Southeast Asian countries, particularly Myanmar, Cambodia, and Laos, has received a significant amount of attention from academics and research organizations during the past few years (Baird and Barney 2017; Chheang 2017; Fox and Castella 2013; Lu and Schönweger 2017; Schoenberger 2017), the close yet complicated food ties between China and Vietnam have appeared much less frequently in discussions, and the

\section{H. Zhang $(\bowtie)$}

S. Rajaratnam School of International Studies (RSIS), Nanyang Technological University, Singapore, Singapore

e-mail: ishzzhang@ntu.edu.sg 
analysis of the potential impacts of the recent changes in China's overall food security strategy and consumption patterns on Vietnam's food sectors is also lacking.

Against this background, this chapter aims to provide a preliminary overview of the macro trends that are emerging in regard to the Chinese food security strategy at the national level and the food preferences at the household level and its implications for Vietnam. Moving away from the traditional micro-perspective analysis which focuses on the economic, social, and environmental impacts of various forms of Chinese agrocapitalism, this chapter adopts a macro-perspective: examining how Vietnam fits into China's new food security strategy as well as the shifting dietary preferences of Chinese consumers and its potential implications for Vietnam's food sectors. Conceptually, this chapter wishes to highlight trans-border aspects of food anxiety. While most of the data used in this chapter are from China's Bureau of Statistics and the Food and Agriculture Organization of the United Nations (FAO) and sources such as government reports, news articles, and existing Chinese and English literature, some insights were drawn from the author's field research observations. From November 5, 2013, to November 14, 2013, the author visited Nanning City in China, Hanoi in Vietnam and the border regions between two countries. During the field study trip, the author had extensive interviews with local scholars, grain traders, farmers, and government officials in both countries. Given the references used, this chapter mainly pronounces the Chinese perspectives and domestic discourses on the country's role in global food trade and food initiatives having a spillover effect beyond its national borders.

The chapter is structured as follows. The section "Paradigm Shift in China's Overall Food Security Strategy" concisely reviews China's food security strategy and its recent changes. Then, the section "Major Changes in Chinese Food Consumption Patterns" analyzes the major changes in Chinese food consumption patterns. After providing a brief background of the various aspects of the food ties between China and Vietnam, the section "Implications for Vietnam" studies the potential implications of the macro changes in China's food security strategy and consumption patterns for Vietnam. A short conclusion is given in the last section. 


\section{Paradigm Shift in China's Overall Food Security Strategy}

For decades, influenced by the painful memories of periodic famines and distrust toward the international market, China has embarked on a policy of achieving self-sufficiency in grain. Largely reacting to Lester Brown's 1994 article "Who Will Feed China"1 (Qureshi 2008), China issued the country's first ever food security White Paper in 1996 (Brown and Halweil 1998; Goldenberg 2015). In this white paper, China officially announced the 95 percent self-sufficiency rate as the bottom line of its food security strategy, and also pledged to achieve absolute self-sufficiency in cereals, including wheat, rice, and corn (State Council, PRC 1996). Significant reduction in China's grain output in the early 2000s led both domestic and international audiences to doubt China's ability to feed itself (Zha and Zhang 2013). During the 2007-2008 global food crisis, China promulgated the first ever National Mid- to Long-Term Food Security Plan (2008-2020) in which the government reiterated its commitment to achieving a 95 percent self-sufficiency rate in grain supply and 100 percent cereal self-sufficiency (State Council, PRC 2008).

With strong political commitment and policy support from the government, China has achieved 12 years of consecutive grain production increase since 2003 (see Table 9.1). Its total grain production reached 616 million tonnes in 2016, over 40 percent higher than that of 2003. In spite of the remarkable growth in domestic grain production, China's total grain imports surged during the same period, reaching 125 million tonnes in 2015. Besides, official targets of the 95 percent self-sufficiency rate for grain and 100 percent for cereals have been breached. Looking into the future, forecasts by international organizations and local institutes indicate that domestic grain demand and the production gap will continue to widen (see Table 9.2).

Imports of other agricultural products also soared. Regarding overall agricultural trade, China was still a net exporter of agricultural products, with USD 2.4 billion trade surplus in 2003. By 2015, China had become the largest importer of agricultural products, with an agricultural trade deficit of USD 50 billion (Ministry of Commerce, P.R. China 
Table 9.1 China's annual grain production and imports

\begin{tabular}{llll}
\hline Year & $\begin{array}{l}\text { Total production } \\
\text { (million tonnes) }\end{array}$ & $\begin{array}{l}\text { Grain total imports } \\
\text { (million tonnes) }\end{array}$ & $\begin{array}{l}\text { Grain imports as \% of } \\
\text { China's total production }\end{array}$ \\
\hline 2003 & 431 & 25.3 & 5.87 \\
2004 & 470 & 33.5 & 7.13 \\
2005 & 484 & 36.5 & 7.54 \\
2006 & 498 & 37.1 & 7.45 \\
2007 & 502 & 37.3 & 7.43 \\
2008 & 529 & 41.3 & 7.81 \\
2009 & 531 & 52.2 & 9.83 \\
2010 & 547 & 67 & 12.25 \\
2011 & 571 & 63.9 & 11.19 \\
2012 & 590 & 80.3 & 13.61 \\
2013 & 602 & 86.5 & 14.37 \\
2014 & 607 & 100 & 16.47 \\
2015 & 621 & 125 & 20.13 \\
2016 & 616 & 114 & 18.50 \\
\hline
\end{tabular}

Source: National Bureau of Statistics, P.R. China $(2017,11-7,12-1)$

Table 9.2 China's grain production and demand forecasts by different organizations

\begin{tabular}{|c|c|c|c|c|}
\hline Organization & $\begin{array}{l}\text { Base } \\
\text { year }\end{array}$ & $\begin{array}{l}\text { Total demand in } \\
2020 \text { (estimated), } \\
\text { million tonnes }\end{array}$ & $\begin{array}{l}\text { Targeted } \\
\text { production by } \\
2020, \text { million } \\
\text { tonnes }\end{array}$ & $\begin{array}{l}\text { Self- } \\
\text { sufficiency } \\
\text { rate }\end{array}$ \\
\hline OECD/FAO & 2013 & 746 & 550 & $73.7 \%$ \\
\hline $\begin{array}{l}\text { Food and Agricultural } \\
\text { Policy Research } \\
\text { Institute }\end{array}$ & 2011 & 726 & 550 & $75.8 \%$ \\
\hline $\begin{array}{l}\text { United States } \\
\text { Department of } \\
\text { Agriculture }\end{array}$ & 2013 & 775 & 550 & $71.0 \%$ \\
\hline $\begin{array}{l}\text { State Bureau of } \\
\text { Statistics, P.R. China }\end{array}$ & 2013 & 725 & 550 & $75.9 \%$ \\
\hline $\begin{array}{l}\text { Institute of Agriculture } \\
\text { Economy, China }\end{array}$ & 2013 & 741 & 550 & $74.2 \%$ \\
\hline
\end{tabular}

Source: Trade Promotion Center of the Ministry of Agriculture, P.R. China (2016, 53-59)

2002-2016). China is now the largest importer of pork, rubber, cotton, dairy and dry whole milk powder, to name but a few.

It is increasingly clear that domestic production has fallen short of rapidly rising demand. Faced with these challenges, in December 2013, 
China began to reform its food security strategy. For the first time, China opted for "domestic supply with moderate imports". While rhetorically, top leaders including the Chinese President Xi Jinping have repeatedly said that China must rely on itself to achieve food security, the basis of China's food security strategy has shifted from grain self-sufficiency to self-sufficiency of overall grain-producing capacity (Ren 2015; Ministry of Agriculture, P.R. China 2017). In other words, China is implementing a new food production policy, which is based on farmland management and application of technology, to ensure the effective supply of agricultural products and grain security. It aims to enhance the crop producing capacity through better land management and utilization of advanced agro-technologies, rather than to have all the food crop at hand and in the barn (FAO 2016). This means more attention will be given to protecting the critical resources, arable land and water in particular, instead of boosting actual grain production through intensive farming. In the meantime, better utilization of international agricultural resources has become an integral part of China's food security strategy.

Although self-sufficiency is still at the center of China's food security strategy, some major changes have taken place. On the one hand, the definition of grain has been redrawn. The central focus of the food security strategy has shifted from ensuring grain self-sufficiency (which covers not only rice, wheat, and corn, but also soybean, root tubers such as potatoes, and coarse grains) to basic self-sufficiency in cereals (wheat, rice, and corn) and absolute security of the staples (rice and wheat). In other words, the new food security strategy demands optimal allocation of resources to safeguard supplies of the country's staples-rice and wheat. Over the past two years, while absolute security of staples has repeatedly been stressed, the country's overall grain-producing capacity, rather than the actual output of a particular year, has become the goal of China's new food security strategy (Ren 2015). In 2016, it is announced that China does not seek a consecutive increase in grain output during the next five years, and the country will focus on consolidating and improving grain output capacity. On the other hand, "moderate imports" officially form part of the national food security strategy. It is the first time in history that "moderate imports" as a policy option have been explicitly accepted. It calls for "more active utilization of the international 
food market and agricultural resources to effectively coordinate and supplement the domestic grain supply" (Cheng and Zhang 2014).

\section{Boosting Domestic Food Production and Global Consequences}

Investing in agricultural technology is considered vital for addressing China's food security problems. China will increase investment and subsidies for the agricultural technology sector to improve land yield, resource efficiency, and labor productivity. In particular, with very limited land and water resources, yield improvement has consequently become the most promising solution to China's food security problem, and China has placed great emphasis on agricultural technologies, particularly Genetically Modified (GM) technologies. To promote the development of GM technology, China made it a development priority in its 12th Five-Year Plan (2011-2015) and the state has invested billions of dollars into GM technology development. In November 2015, China National Chemical Corp (ChemChina) entered talks to buy the Swissbased Syngenta (one of the biggest seeds and pesticides company in the world) for USD 41.7 billion. Subsequently, ChemChina increased its offer to more than USD 43 billion, and successfully acquired Syngenta in May 2017. This is the largest overseas acquisition by a Chinese company to date. Being the world's largest agricultural producer and leading food importer, China's attitude toward GMOs will have a far-reaching impact on future GM research and investment and the global agricultural industry (Zhang 2016a).

Confronted with limited land and fresh water resources, China is turning toward its "blue lands" (including its territorial waters and Exclusive Economic Zones-EEZs) for food. At the 18th Party Congress, Chinese leaders pledged to enhance China's capacity for exploiting marine resources. Development of aquaculture and offshore fishing is being prioritized. In fact, the food security concern has been the main driver for two key structural changes that are taking place in China's fishery sector: the rapid growth of the aquaculture sector and outward expansion of the marine fishery sector. While these structural changes 
tend to have a positive contribution to China's food security strategy at least in the short term, they are generating consequences which go beyond the fishery sector and the national boundary. For instance, more and more fishing incidents involving Chinese fishermen have triggered greater conflicts in regional waters. The outward and rapid expansion of China's marine fishery sector has put further pressure on the already limited stocks in the world and could further weaken the already fragile marine ecology (Greenpeace 2015; Mallory 2013; Zhang 2016b).

Furthermore, while China recognizes that the agricultural sector must be modernized, the prevalence of small, fragmented land plots and unproductive farms render the task daunting, as pointed out by Chen Xiwen (2017), the former head of the Chinese Communist Party Office on rural policy and deputy head of the party's office of financial affairs. China's household-based smallholding agriculture has inherent limitations. Chief among these are the high costs and risks in gaining the capital, the skills, and especially the market access needed for commoditized agriculture, which deterred many small agriculturalists from making the transition. As such, China began to formulate and implement its agricultural modernization program in the mid-1990s, which aimed to transform the country's small-scale, household-based agriculture into a modernized agriculture, with the emphasis on increased scale, specialized production of higher-value goods, and market-orientation (Zhang 2012).

\section{Agriculture Goes Global}

China's outward-looking food security approach has three major aspects. First, China aims to import more food from the international market. In the coming years, not only imports of soybeans, cotton, edible crops, sugar, dairy, and other agricultural products will increase, more cereal, mainly maize, will also be imported from the international market. With China's increasing reliance on imports, the country's agricultural import diversification will become critical for global agricultural development. China's current agricultural imports are limited to a few agricultural products and national suppliers, particularly the United States. Such diversification entails import of various agricultural products via multiple 
channels, regions, and approaches. Its purpose is to reduce risks caused by overdependence on a few suppliers, particularly the United States (Wu and Zhang 2016).

The second aspect is the expansion of overseas agricultural investment. Stated-owned agribusiness, private companies, and even individual farmers from China have ventured abroad through leasing or purchasing foreign agricultural land ranging from Southeast Asia to Russia's Far East, Central Asia, Australia, New Zealand, Africa and Latin America. China is supporting its agricultural companies-both the state-owned enterprises such as $\mathrm{COFCO}$ and the Beidahuang Group as well as private companies such as Shuanghui and Bright Groups-to become global players that can compete with established global agribusiness giants such as Cargill. It is estimated that over the past five years, China's overseas food-related mergers and acquisitions (M\&A) reached USD 20 billion. This includes Shuanghui International's USD 4.7 billion takeover of American company Smithfield Food in 2013, the acquisition of Dutch grain trader Nidera and Singapore-based Noble Group's agribusiness by China National Cereals, Oils, and Foodstuffs Corporation, and ChemChina's USD 41.7 billion purchase of Syngenta (Zhang 2016a).

Pushing forward the new model of global agricultural cooperation is the third aspect of China's global agricultural policy. China aims to further liberalize its agricultural sector to enhance the country's food security. Based on the principle of mutually beneficial cooperation, China gives economic and technological support to developing the agricultural sector in neighboring countries. China is also enhancing connectivity with neighboring countries by establishing more cross-border trade centers and free trade zones, and improving diplomatic ties for cross-border investment under the framework of China's Belt and Road Initiativethe trillion-dollar economic integration undertaking proposed by China that focuses on connectivity and cooperation between Eurasian countries As the most populous country in the world and a major food trader, China's food security is highly dependent on global food trade and global food security. For this reason, the Chinese government believes it has both interest and responsibility to contribute to global food security. Strengthening global food security is seen as a critical means to safeguard China's own food security. Apart from providing agricultural assistance to 
developing countries to enhance their agricultural production, China is emerging as a major donor of food in the world. In 2011, when the food security situation exacerbated in East Africa, China provided close to USD 70 million worth of food aid to help countries combat hunger. China has increased its donations to the Food and Agricultural Organization (FAO), the World Food Program and the International Agricultural Consultative Group, and now plays a stronger role in the newly reformed FAO Committee on Food Security (Zha and Zhang 2013). Nevertheless, it should be noted that some are quite critical of China's global agricultural engagement. On the one hand, as the food security emerges as a top international concern after the global food crisis in 2007/2008, many feared that China had embarked on a statesponsored quest to lock up vast tracts of land in developing countries of Africa, Southeast Asia, Latin America, and Central Asia to grow food to feed itself (Financial Times 2008). Many news reports and studies accused China of playing a leading role in land-based foreign investment in agriculture, usually being criticized as a so-called land grabber or neocolonial power (Hofman and Ho 2012).

\section{Major Changes in Chinese Food Consumption Patterns}

\section{Moving Away from Grains}

Since the Reform and Opening up in 1978, China's economy has experienced phenomenal growth. Per capita income of Chinese residents increased remarkably as well. The per capita annual income of urban residents reached USD 4890 in 2015, up from merely USD 52.7 in 1978; per capita annual income of the rural residents amounted USD 1657 in 2015, representing over 90 times of increase as compared to that of 1978 (National Bureau of Statistics, P.R. China 2017). In the meanwhile, China also experienced very rapid urbanization. In the late 1970s, over 80 percent of Chinese lived in rural areas, yet, by 2015, China's urbanization rate reached 56.1 percent (National Bureau of Statistics, P.R. China 2017). 
Table 9.3 Trend in per capita consumption of major food products of China (kg)

\begin{tabular}{lllll}
\hline & 1980 & 1986 & 2010 & $2020 f$ \\
\hline Grain & 190.3 & 207.1 & 148 & 128.4 \\
Vegetables & 134 & na & 175.4 & 209.2 \\
Fruits & 6.3 & na & 55.9 & 92 \\
Edible oil & 1.7 & na & 12.6 & na \\
Sugar & 1.6 & na & 5.6 & 8.3 \\
Poultry and meat & 12.6 & na & 48.9 & 62.9 \\
Aquatic products & 2 & na & 21.2 & 28.3 \\
Milk & 1.4 & na & 26.9 & 45.9 \\
Eggs & 1.8 & na & 12.1 & 14.5 \\
\hline
\end{tabular}

Source: Han $(2014,59)$

Against extraordinary income growth and rapid urbanization, the Chinese dietary pattern has changed notably, and the trend is still ongoing.

As shown in Table 9.3, the Chinese diet is moving away from grain. China's per capita grain consumption has been declining steadily since it peaked in 1986. By 2010, per capita grain consumption has fallen by nearly 30 percent as compared to the peak level of 1986 and it is forecasted to drop further to $128.4 \mathrm{~kg}$ by 2020 . By contrast, per capita consumption of the major non-grain food products has all increased, though at varied rates. While per capita consumption of vegetables has modestly increased to $175 \mathrm{~kg}$ per capita from $134 \mathrm{~kg}$ in 1980, which is expected to reach $209.2 \mathrm{~kg}$ in 2020, the per capita consumption of fruits, meat, sugar, aquaculture products, milk, and eggs have experienced explosive growth during the same period. From 1980 to 2010, China's per capita annual consumption of fruits had increased 7.8 times, poultry and meat 2.8 times, aquatic products 9.6 times, milk over 18 times. The shift in the Chinese diet is expected to continue as seen in Table 9.3.

\section{A Widening Dichotomy in Food Consumption Patterns}

Beneath the overall shift of China's diet as discussed above, a widening dichotomy in China's food consumption patterns is surfacing along with the growing income and a huge rural-urban divide. Similar to the experience of other countries, China's rapid economic growth in the past decades is associated with soaring inequality among its citizens. China's 
income inequality has exploded over the past decades. In 1980, China's Gini coefficient (a measure of inequality) stood at 0.3 , according to People's Daily; in 2012, it was at 0.49 and the World Bank considers a coefficient above 0.40 to represent severe income inequality. Although the official statistics indicate China's Gini coefficient has dropped slightly since 2012, it is still among the highest in the world, and some scholars even suggested the official number is an underestimation. For example, an estimate by economists at the Southwest University of Finance and Economics in Chengdu put the Gini coefficient at 0.61 in 2010 (Wildau and Mitchell 2016). Despite the controversies regarding China's Gini coefficient, what is clear is that while the size of China's middle and highincome group is expanding, a significant number of Chinese remain poor. One-third of the country's wealth is owned by the top 1 percent of households, while the bottom 25 percent account for only 1 percent of wealth (Xie and Jin 2015). Furthermore, based on China's new poverty line, there are still over 100 million Chinese living under it. This income inequality has thus created a dichotomy in food consumption patterns of the Chinese consumers.

On the one hand, the affluent middle-income and high-income consumers are experiencing growing anxieties over the quality and safety of the food products, particularly those produced domestically. For three consecutive years, food safety has been ranked as number one social concern by the Chinese, according to opinion polls. The 2014 China Comprehensive Moderate Prosperity Index Survey revealed that 53.3 percent of the interviewees were dissatisfied with China's food safety situation (Center for Coordination and Innovation of Food Safety Governance 2014).

In 2015, the Chinese Ministry of Environmental Protection and the Ministry of Land and Resources released the first ever results of a nationwide soil pollution survey that took place from 2005 to 2013. The survey result indicates that 16.1 percent of China's soil and 19.4 percent of its arable land showed contamination with inorganic chemicals like cadmium, nickel, and arsenic (BBC 2014). Contamination of food by heavy metals_-particularly cadmium, lead, mercury, and arsenic - is of great concern as it affects staple foods including rice and vegetables. People who consume high levels of heavy metals over an extended time can 
develop organ damage and weakened bones, among other medical conditions (Larson 2014).

Shaped by growing distrust toward domestic food produce as well as rising demand for a different variety of food products, Chinese consumers are increasingly turning away from domestic produce to imports, including agricultural products from Southeast Asian countries. For example, according to Taobao-China's biggest online shopping website-spending by the average e-shopper on organic and imported food and beverages has expanded eightfold over the past three years as many popular online offerings, such as organic baby foods, rice, and tea, are not available in local stores (Youchi 2016).

On the other hand, the poor's food anxiety is attributed to the rising food prices, particularly grain and meat products. The Chinese government heavily relies on price interventions and trade restrictions - raising domestic purchase prices for rice, wheat, corn, pork, beef, sugar, and so on, and limiting imports to boost domestic production. As a result, domestic food prices have risen significantly over the past few years, and high domestic food prices have generated constant anxiety from lower income groups over the affordability of food in China (Source). Taking rice and wheat, for example, since the introduction of the minimum grain purchase price policy in 2004, the grain market has been tightly controlled by the government which places grain production increase as the ultimate objective. Since 2004, China has gradually raised the grain purchase prices to boost grain production, particularly amid the global food crisis in 2007/2008. As seen in Table 9.4, China's minimum purchase price for Japonica rice has more than doubled between 2007 and $2014 .^{2}$ In the past three years, the minimum purchase price for Japonica rice has remained unchanged which has been against the background of a significant drop in global rice prices. The same pattern is being observed in the case of wheat. Given the dominating effects of government's minimum grain purchase price on the domestic grain markets, the domestic retail prices have increased significantly over the past few years. It is revealed by Chinese top government officials, that on average, the current domestic grain prices are 50 percent higher than the international grain prices (Chen 2017). The high domestic grain prices become a huge burden for domestic consumers, and it is estimated that the Chinese con- 
Table 9.4 China's minimum grain purchase price for rice and wheat (RMB/kg)

\begin{tabular}{lll}
\hline Year & Japonica rice & Mixed wheat \\
\hline 2004 & 1.50 & Nil \\
2005 & 1.50 & Nil \\
2006 & 1.50 & 1.38 \\
2007 & 1.50 & 1.38 \\
2008 & 1.64 & 1.44 \\
2009 & 1.90 & 1.66 \\
2010 & 2.10 & 1.72 \\
2011 & 2.56 & 1.86 \\
2012 & 2.80 & 2.04 \\
2013 & 3.00 & 2.24 \\
2014 & 3.10 & 2.36 \\
2015 & 3.10 & 2.36 \\
2016 & 3.10 & 2.36 \\
\hline
\end{tabular}

Source: National Development and Reform Commission, P.R. China (2004-2016)

sumers are paying over USD 40 billion a year due to the grain price gaps. Given the fact that the share of grains, rice, and wheat in particular is much higher in the poor consumers' diet, high domestic grain prices have been motivating the poor consumers to switch for cheap rice and wheat from foreign countries, such as Vietnam, Thailand, and Myanmar (Li 2015). The cheap foreign imported and smuggled grains are not only favored by low-income urban consumers but also desired by the rural residents, including rice and wheat farmers. For instance, the investigation reports of several high-profile rice smuggling cases (primarily from Vietnam) revealed that the smuggled rice was often purchased by farmers who prefer to sell their own produce to the government at higher prices set by the government and rely on the cheap smuggled rice for their own consumption. In some cases, farmers purchased the smuggled rice and resold it to the government to make a profit (GrainNews 2015).

Not only grains are being tightly controlled, other key food products such as pork and sugar have been closely regulated by the government as well. Taking pork as an example, China has built a pork reserve following a fatal outbreak of PRRS (also known as porcine blue-ear disease) in 2006 that left millions of pigs dead and pork prices going through the roof. As a result, owing to a supply and demand gap as well as rapidly rising production costs, domestic pork price has skyrocketed in recent years, despite intermittent ups and downs (Lockett 2016). 
Again, as in the case of grain, with the soaring pork price and limited liberalization of China's pork markets, the price gap between China's and the international pork market has widened quickly. By the end of 2016, China's domestic pork price was more than 2.5 times of the price level in the United States (Gale 2017). Not surprisingly, the pork price rises have become so large that they hurt the affordability of domestic consumers particularly the low-income consumers. The huge domestic and international price gap has spurred China's pork imports and smuggling of frozen meats, which is preferred by the price sensitive consumers despite potential safety and quality concerns.

\section{Implications for Vietnam}

As China continues to grow, albeit at a lower rate, and opened its borders under the country's high-profile Belt and Road Initiative (BRI), the effects on the agricultural sector and food security of Vietnam will be much more significant. Taking the rice sector as an example, China's annual rice production is over 200 million tonnes. This represents more than 25 percent of global rice production and nearly five times the size of the world's export market, in which Vietnam is one of the biggest suppliers. Given the scale of China's rice production and consumption as well as the thinly traded market for rice, changes in China's food security strategy, rice policy, in particular, will have profound impacts on Vietnam not least owing to Vietnam's reliance on rice both as a staple and a source of export revenue (Vietrade 2016). While rice may be the most visible agricultural commodity, this same story may well be replicated across a range of food products, such as fishery, sugar, fruits, and vegetables. The rest of the section reviews various aspects of food ties between China and Vietnam, including not only the formal agricultural trade and investment ties, agricultural technology and input cooperation but also the massive food smugglings and illegal farm labors across the land borders, and discusses how these trends are shaped and will continue to be shaped by the changing dynamics in China's food systems. 


\section{Formal and "Informal" Agricultural and Food Trade}

Agricultural trade between China and Vietnam, in parallel with the overall trend of trade between China and Southeast Asian countries, has expanded phenomenally over the past decade, particularly since the signing of "the Framework Agreement on Comprehensive Economic Cooperation between the People's Republic of China and the Association of Southeast Asian Nations" in Phnom Penh, Cambodia in 2002. As seen in Table 9.5, China's agricultural trade with Vietnam has increased from USD 430 million in 2004 to over USD 6.7 billion in 2016, hence jumped up by over 1300 percent during this period. Among the bilateral agricultural trade, China's agricultural exports to Vietnam reached USD 3.87 billion in 2016, up from USD 240 million in 2004, whereas agricultural imports from Vietnam increased from USD 191 million in 2004 to USD 2.84 billion in 2016 .

In terms of agricultural trade structure, China's main exports to Vietnam include oranges, apples, garlic, soybean meal, feathers, prepared intestines; and Vietnam is the top supplier of rice, fruits, and nuts as well as sugar to China. According to data of China's Ministry of Commerce, although Vietnamese rice exports to China in 2016 inched down against the previous year, Vietnam remained China's largest rice supplier (Ministry of Commerce, P.R. China 2002-2016). From January to April 2017, Vietnam's total fragrant rice exports amounted to over 355,000 tonnes, with China alone accounting for a staggering 46 percent (Vietnamnet 2017a). China is also becoming one of the key markets for Vietnam's cashew and fishery exports. China is currently the third largest

Table 9.5 China and Vietnam agricultural trade (USD million)

\begin{tabular}{|c|c|c|c|c|c|}
\hline \multicolumn{6}{|c|}{ China agricultural exports to Vietnam } \\
\hline & 2004 & 2005 & 2014 & 2015 & 2016 \\
\hline Vietnam & 240.02 & 305.59 & 2988.63 & 3430.61 & 3869.65 \\
\hline ASEAN & 2118.33 & 2422.46 & $13,539.20$ & $14,753.72$ & $15,377.70$ \\
\hline \multicolumn{6}{|c|}{ China agricultural imports from Vietnam } \\
\hline & 2004 & 2005 & 2014 & 2015 & 2016 \\
\hline Vietnam & 191.46 & 206.59 & 2249.98 & 2717.57 & 2837.32 \\
\hline ASEAN & 3715.30 & 3681.67 & $16,032.88$ & $15,806.56$ & $14,500.31$ \\
\hline
\end{tabular}

Source: Ministry of Commerce, P.R. China (2002-2016, 20) 
importer of Vietnamese cashew (Vietnam's cashew exports, nearly USD 3 billion, account for over 40 percent of the global total); and, in the first quarter of 2017, China overtook the United States as the largest importer of Vietnamese catfish (Vietnamnet 2017b).

Apart from agricultural products, bilateral trade of agricultural inputs, including seeds, fertilizers, pesticides, and food additives are booming as well. For instance, Vietnam spends on average USD 774 million each year on imports of pesticides and insecticides, 90 percent of which come from China (An 2016); and Vietnam imports nearly 70 percent of hybrid rice seeds from China (Pham 2017). In order to promote the agricultural product trade, China and Vietnam signed a memorandum of understanding on cooperation in the field of trade of agricultural products in 2013 (Zhao 2015).

The phenomenal agricultural trade between the two sides is attributed to a variety of reasons including China's domestic production shortage, diversification of the Chinese diet, price differences, and distrust toward domestic food produce. In the case of sugar, the persistent domestic demand and supply gap has been the key factor that contributes to large sugar imports (Ministry of Agriculture, P.R. China 2015). Regarding rice, after the outbreaks of several safety scandals related to toxic rice, more and more Chinese consumers have been buying imported rice. While some are willing to pay up to ten times the price for the imported Japanese rice, others are buying rice from Southeast Asian countries, particularly Thailand and Vietnam as an alternative. In the past few years, the domestic and international rice price difference has also been one of the key drivers behind China's massive imports of rice from Southeast Asian countries, particularly for the state-owned grain traders who are granted with China's rice import quota. Regarding fruits, diversification of diet has been the primary driver. With the Chinese consumers' growing taste for fresh fruit, demand for tropical fruits from Southeast Asian countries, particularly Thailand and Vietnam, has been on the rise as well. More and more Chinese consumers purchase durian, longan, mangosteen, and coconut from Southeast Asia. Southeast Asian countries are the biggest sources of fruit imports for China, with Vietnam and Thailand accounting for 46 percent of China's total fruits and nuts imports in 2015 (Ministry of Commerce, P.R. China 2002-2016). 
On the other hand, as Chinese consumers' food preferences change, some of the domestic food products, particularly the low end manufactured and processed food products, are being increasingly shipped to neighboring countries including Vietnam. Taking the instant noodle, for example, as Chinese consumers are turning away from instant noodles, Chinese producers are entering growing markets like Vietnam. In the past, for hundreds of millions of peasant workers in China, instant noodles were a convenient choice for a meal because they were available for a few cents in every convenience store. However, rising wages have improved living standards and expectations for millions of peasant workers who are increasingly willing to pay more for better and healthier food, instead of a 25-cent bowl of instant noodles. To make the matter worse, instant noodles have developed a bad reputation in China owning to scandals and rumors and a 2012 food-poisoning incident and longstanding allegations that instant noodles are contaminated with plasticizers (Minter 2016). As a result, China's instant noodle makers are struggling to re-start growth. One option is to export noodles to other emerging Asian economies such as Vietnam, where consumption is still growing along with the manufacturing sector (Minter 2016).

In addition to the formal agricultural trade, the changing food dynamics in China have also resulted in pervasive smuggling of food products via the land borders between Vietnam and Myanmar and China's Yunnan and Guangxi provinces. Rice has been the most common food product which is being smuggled into China from Southeast Asian countries. For instance, in 2014 it was estimated that over 3 million tonnes of rice have been smuggled from Vietnam and Myanmar to China via the land borders. Despite a series of anti-smuggling campaigns, in 2015, around 2.6-2.7 million tonnes of rice were smuggled into China (see Table 9.6). The former chief of China's cabinet-level State Council's rural policy Unit-Chen Xiwen also admitted that it is likely that more rice is being smuggled into China than the volume sent in legal shipments. Rice is first brought from Vietnam and Myanmar to China's border cities in Guangxi and Yunnan province. From there it is shipped by rail to China's inland provinces for sale. Smuggled rice is sold to processors or mills, processed and sold, or mixed with domestic rice. 
Table 9.6 China's rice imports and smuggling

\begin{tabular}{lll}
\hline & 2014 & 2015 \\
\hline China's official import data & 2.6 & 3.4 \\
FAO import data & 5.9 & 6.1 \\
Data from rice exporters & $\mathrm{Nil}$ & 6.0 \\
Smuggled amount & 3.3 & $2.6-2.7$ \\
\hline
\end{tabular}

Source: Ministry of Commerce, P.R. China $(2016,11)$; FAO (2016)

There are multiple reasons why so much rice is being smuggled into China. For a start, with growing diversification of the Chinese diet, Thai rice is gaining popularity in China among the middle-income consumers. Secondly, as the domestic rice price rose, cheap rice from Vietnam and Myanmar is being preferred by low-income consumers in the cities and by rural residents. Third, the widespread concerns over the heavy metal contamination of domestic rice further pushed consumers to opt for foreign rice. In China, rice can be priced up to USD 154 per tonne higher than in rice-growing countries in Southeast Asia. As discussed earlier, this is largely due to Chinese authorities setting a high government purchasing price to protect farmers' interests. Also, under China's rice trading system, the quota is mostly being granted to state-owned enterprises, which leave the private rice processors with very limited access to cheap foreign rice. As a result, some opt to purchase smuggled rice. The massive rice smuggling has been recognized as a major threat to China's food security and consumer safety (General Administration of Customs of China 2014).

For similar reasons, sugar and frozen meats are also being smuggled into China via the land borders on massive scales. As much as 2 million tonnes of sugar were smuggled into the country in 2015-2016, up from 800,000 tonnes a year earlier. While the government has sought to curb the practice in recent years, the large gap between domestic and global prices makes it hard to control. Most smuggled sugar is believed to be produced in India and Thailand and then transshipped to Myanmar or Vietnam before entering China, it said in an April report (Bloomberg News 2016). As for beef, it was estimated that over 2 million tonnes of frozen beef were smuggled into China in 2013, which made up over 20 percent of total domestic consumption in 2013. In the past, frozen beef 
was smuggled to China via sea ports such as Guangzhou. However, due to the government's crackdown, more frozen beef began to find its way into China via the land borders between Vietnam and Yunnan and Guangxi provinces in China. The smuggled pork, however, is mostly from Southeast Asian countries, Vietnam in particular. Since 2003, due to Foot and Mouth disease of swine, China has banned the import of pork from Vietnam. Yet in recent years, due to a rapid surge in China's domestic pork price (see above), the pork price in China has become much higher than that of Vietnam. For instance, as of November 2016, this price gap is about USD 615 per tonne. Driven by this high potential profit, pork smuggling has surged. In November 2016, official reports indicate that as high as 10,000 pigs could be smuggled into China via the land borders on a daily basis. Similar to other products, the smuggled pork would be quickly distributed to other Chinese provinces. In the past, there were even reports suggesting that foreign "zombie" (frozen meat which has been stored for decades) meats were also smuggled into China (Yu 2015). While the government has taken considerable efforts to combat the meat smuggling and the general public has been duly informed about the potential safety risks of the smuggled meat, meat smuggling is still flourishing as these cheap meats are being demanded by pork processors, meat retailers, and restaurants, given the large number of Chinese consumers who are still very sensitive to meat prices. The rising concerns over the excessive use of growth enhancer and lean meat powder in the domestic hog sector have further motivated Chinese consumers to switch to imported meats, including the smuggled frozen meats (Cai et al. 2015).

Looking into the future, the agricultural trade between China and Vietnam is expected to expand even further as China is seeking to reduce its over-reliance on the United States for food imports under its new food security strategy. Aiming for USD 100 billion in bilateral trade turnover, Vietnam also intends to export more of its processed agricultural products, seafood, and electronic and consumer products to the Chinese market (VietnamNet 2017). However, as China is determined to achieve self-sufficiency in staples, including wheat and rice, it is unlikely that Vietnam's formal rice exports to China will expand even further. This is particularly the case as concerns are mounting on adverse impacts of imported rice on China's domestic rice production. In the meanwhile, as 
Chinese consumers are willing to pay more for better and healthier food and the Chinese government is looking to curb the country's overuse of pesticides and chemical fertilizers that have largely contributed to the large scale contamination of arable land, overcapacity in the low end food manufacturing sector (including the counterfeited food sector) and fertilizer and pesticide sectors have pressured these manufactures to explore new markets, particularly fast-developing Vietnam.

Close agricultural and food trade with China presents both opportunities and challenges to the Vietnamese food sectors. On the positive side, booming agricultural and food trade has not only greatly enriched the diet of the people from both sides but also contributed to income growth of farmers as well as food security of the region. On the other hand, however, the huge formal and informal agricultural and food trade between the two countries create enormous challenges to Vietnam as well. Given the critical role of rice farming in the agricultural sector and rice consumption in the Vietnamese diet, over-reliance on China as the main export market breeds risks for the Vietnamese rice sector. In times of rice glut, Vietnam will be at the mercy of China's rice import policies. In the past few years, oversupply of rice in the global market has been dragging down prices in the world market, affecting rice exporters including Vietnam. Worse still, China's decision to diversify its rice import sources and curb massive rice smuggling from Vietnam via the land borders have created further hardships for the Vietnamese rice producers and traders. In times of supply shortages, however, huge demand from China could contribute to surge in domestic rice price as in the case of the global food crisis in 2007/2008, resulting in panic buying and large scale food anxiety in Vietnam (see Gorman, this volume). In 2007/2008, Vietnam introduced a rice export ban to ensure stability of domestic rice supply. Yet, with China as the biggest buyer of Vietnamese rice and pervasive border smuggling, it will be politically, diplomatically, and practically challenging for Vietnam to ban rice export to China, should another food crisis occur.

Furthermore, it is evidenced that when China took tougher action against counterfeited and substandard food products in the cities, many of these products quickly flooded the rural markets where surveillance is lacking and farmers are much more price sensitive. Given the lax control 
over cross-border trade and Vietnamese consumers' relative sensitivity to prices, these products could also be exported or smuggled to Vietnam via the land borders, posing safety threats to local consumers. Already, some of the substandard Chinese food products were found in the Vietnamese market (VietNamNet Bridge 2016a). In the past few years, rumors of tainted milk, fake chicken eggs from China and rice paper wraps made from plastic have horrified consumers in Vietnam. In Vietnam, it was suggested that surge in cancer was related to massive food smuggling from China into Vietnam for sale in local markets due to widespread corruption among Vietnamese border guards (Thuy 2012). Many smuggled food products are believed to be adulterated or containing cancer-causing agents, kept in toxic plastic bags or stored without any concern for minimum hygienic standards or health safety regulations. A related issue is the use of fertilizers, pesticides, insecticides, and food additives. In recent years, excessive use of chemical inputs, mostly imported or smuggled from China, has been identified as one of the leading cause for environmental pollution and blamed by authorities for the rocketing cancer rate (An 2016). In fact, given the close food ties between the two countries, news or rumors related to food safety scandals in China could quickly hit home for many Vietnamese consumers (as they already have, see Part II, this volume).

\section{Investment, Agricultural Technologies, and Fishery}

By the end of 2015, China's accumulated overseas Agricultural Foreign Direct Investment reached USD 11.74 billion. It is estimated that there were over 1300 Chinese agricultural companies operating in 85 countries, ranging from plantation to animal husbandry, to fishery and related sectors. By the end of 2013, China's agricultural investment in Asia produced 53 million tonnes of grain and 41.5 million tonnes of cash crops (Zhang and Cheng 2016). Apart from the direct investment, more and more Chinese companies are expanding their presence overseas via Merger and Acquisition (M\&A). From 2010 to 2014, China's agricultural related M\&A totaled USD 18.5 billion.

In November 2016, China issued the country's five-year plan for the rural economy which includes four paragraphs on "coordinated utilization 
of domestic and foreign markets and resources" (National Development and Reform Commission, P.R. China 2016). It specified that China's agricultural going global would be based on the periphery through deepening cooperation with "neighboring countries" while strengthening agricultural ties with South America, consolidating agricultural cooperation with Africa, and thinking globally. This emphasizes the importance of its southern neighbors as key targets for China's agricultural investment and aids.

China's agricultural investment in continental Southeast Asia dates back to the 1990s. Although China's agricultural investment has mainly concentrated in Laos and Myanmar under China's Opium Replacement Program since the 1990s and recently in Cambodia, China's investment in Vietnam's agricultural sector has been impressive as well. By the end of 2014, China had 112 agricultural investment projects in Vietnam, with total contracts amounting to nearly USD 280 million (Ministry of Commerce, P.R. China 2016). During the visit of Vietnam's President Tran Dai Quang to China in May 2017, he said Vietnam hopes China could invest more in Vietnam's agriculture, one of the seven priority sectors (Van 2017). It can be expected that under China's Belt and Road initiative, China's investment in Vietnam's agricultural and food sector will continue to expand.

As an agricultural country rich in agricultural products and seafood, but with a low level of variety improvement, storage, and processing technology (Vietnam Business Forum 2014), Vietnam opts for large scale investment in its agricultural sectors to enhance food production and reduce rural poverty (Viet Nam News 2017). In this aspect, China's renewed interest in developing the region's agricultural sector thus provides a huge opportunity for Vietnam to boost agricultural productivity and diversification and build sustainable food supply chains. Nevertheless, large inflow of Chinese investment into Vietnam's agricultural and food sectors inevitably generate social, economic and even political concerns, particularly at the local level. As being witnessed in Cambodia, Laos, and Myanmar, with large Chinese presence in these countries' agricultural sectors, local and international media spawns debate in land grabbing discourse concerning issues of national sovereignty and independence. Furthermore, as many of the agricultural investment deals involve large pieces of land, there are growing concerns of the negative impacts of Chinese investment on local small-scale farmers. For instance, in 
Northern Myanmar, China's agricultural investment has caused environmental, social, and political conflict with local farmers who have been forcibly displaced from their land (Woods 2014).

What's more, Chinese investment in the region's agricultural sector, if not properly managed, could lead to displacement of local farmers and environmental degradation. Next, as the biggest rice producer and consumer in the world, technological development in China could have a direct impact on Vietnam's rice production and consumption. For decades, to boost rice production, China has invested heavily in hybrid rice technologies. Currently, well over half of China's total rice-growing area is planted with rice hybrids, making the country by far the world's largest producer of the crop. While hybrid rice plantation has greatly contributed to the phenomenal expansion of China's total rice production, in recent years, some serious problems emerged. Among these problems, as discussed in the previous section, rice contamination by heavy metal, has become a top threat to consumer safety. While industrial pollution and overuse of chemical inputs are among the main causes of heavy mental contamination, it is also discovered that some of the hybrid rice varieties, such as Indica-Japonica Hybrids-Super-rice, have a high propensity to absorb cadmium (Forum on Health, Environment and Development_FORHEAD 2014). As Vietnam's hybrid rice seed sector relies heavily on imports from China, with rapid industrialization and urbanization, "cadmium rice" could be soon found in Vietnam. Perhaps, a bigger challenge would be the GM rice. China's embrace of GM rice technologies could have major implications on Vietnam's rice sector. As the powerhouse for GM rice technology, China could easily dominate Vietnam's GM rice production as in the case of hybrid rice. This could trigger national security concerns. While the Vietnamese government has been quite supportive of GM technologies, the social resistance is considerably high (Lien 2015). As in the case of China, many Chinese security experts claim that GM food is the United States' bioweapon against the Chinese people, the "China factor" (Zhang 2016c) could further complicate the domestic debates on GM food. Last but not least, while a lot can be learned by Vietnam from China's experience in agricultural development over the past decades, some of the bad practices from China could also be replicated in Vietnam either through Chinese agricultural investors or through tens of thousands of legal and 
illegal Vietnamese farmers working in China, as food ties between the two sides become ever closer. In fact, there were reports suggesting that some Vietnamese went to China to learn the gutter oil techniques, ${ }^{3}$ and some of the illegal chemical additives found in Vietnamese food sectors originated from China (VietNamNet Bridge 2016b).

Furthermore, as China is determined to expand its fishery sector to meet the country's rising demand for food, competition between China and Vietnam over the limited fishery resources from the disputed waters in the South China Sea ${ }^{4}$ could intensify. Traditionally, inshore fishing has been the major marine fishing operation in China, as nearly 90 percent of China's total marine catch in 1985 was inshore. However, by 2002, this figure dropped to 64.5 percent (Bureau of Fisheries of Ministry of Agriculture, P.R China 1986, 2003). While data at the national level is unavailable after 2002, data from local levels continues to suggest the shift from inshore to offshore fishing. The production of inshore fishing dropped to 60 percent of Guangzhou city's total marine catch in 2006, and 50.5 percent in Hainan province by 2007 (Zhang 2016b). Due to overfishing, pollution and land reclamation, fish stocks in China's traditional fishing grounds are depleted. Seventy percent of China's beaches are polluted and 50 percent of tidal wetlands have disappeared. The Bohai fishing ground, Zhoushan fishing ground, the other fishing grounds near coastal waters in the South China Sea, and the Beibu Gulf fishing grounds now exist in name only (Tang 2016). In particular, big fish in China's Bohai are almost completely gone and the annual production of small fish is less than 10 percent of its peak amount (Beijing Times 2015). As the depletion of fishery resources mainly occurs in inshore waters, China consequently focuses more on expanding offshore fishing.

To ensure a stable supply of fishery products and to protect the fishermen's livelihood, China encourages its fishermen to go further out to sea. According to President Xi Jinping, Chinese fishermen need to "build bigger ships and venture even further into the oceans and catch bigger fish" (Chan 2013). In practical terms that means offshore fishing in waters near the Spratly islands and distant water fishing. However, offshore fishing in waters near the Spratly Islands is not covered by China's South China Sea fishing ban (May 16 to August 1 annually). Fishermen who go there would receive additional fishing-fuel subsidies under the Special 
Fishing-Fuel Subsidy for Fishing In The Spratly Islands Programme introduced in 1995 (Zhang 2016b).

Similarly for Vietnam, due to overfishing and excess capacity in its coastal and inshore fishery, the country has implemented strategies since the late 1990s to limit coastal fishing effort and develop offshore fisheries. In 1998, construction of new vessels less than 20 horsepower was banned and a financial subsidy was provided to build bigger vessels capable of sailing to offshore waters (Pomeroy 2010; Pomeroy et al. 2009). The outward expansion of Vietnamese marine fishery has been remarkable. In 2012, the near-shore and offshore catching output was in balance, with a rate of 50.6 percent and 49.4 percent. This is a significant change compared to that in 2001, when near-shore fishing accounted for 69.2 percent of the total marine catch. Furthermore, Vietnam is expected to reach a rate of 64 percent offshore-36 percent inshore by 2020 (Le 2016). In a recent development, so-called Vietnamese blue boats have become active in illegal fishing in the South Pacific (Forum Fisheries Agency 2017). As a result, in recent years, there have been a growing number of maritime incidents involving the two countries' fishermen in the South China Sea. Some of the maritime incidents even triggered diplomatic and even security tensions between China and Vietnam. For instance, in July 2016, Vietnam has accused the Chinese coastguard of sinking a fishing boat in the disputed waters of the South China Sea and demanded compensation from China (Straits Times 2016).

\section{Conclusion}

The paradigm shifts of China's overall food security strategy and the Chinese consumers' food preferences have important implications for global food security and food markets beyond its borders, particularly Vietnam (see Gorman, this volume). China's renewed interest in developing the region's agricultural sector could provide huge economic opportunities for Vietnam's agricultural and food sectors. Nevertheless, as food ties between the two countries strengthen, Vietnam's food markets will also be increasingly subject to forces beyond its borders. For instance, food shortages in China could easily trigger panic buying in Vietnam. Moreover, the 
Chinese consumers' growingly diversified tastes for different varieties of food products as well as concerns toward safety and quality of domestic produce could create further demands for food products from Vietnam, which could generate more income for the farmers. However, what should be noted is that the massive smuggling of the food products such as rice, sugar, and frozen meat, though providing considerable benefits to both countries, could eventually hamper the agricultural ties between the two sides in the future, if left unmanaged. For example, massive rice smuggling across the land borders is damaging the reputation of Vietnamese rice in the Chinese market.

Furthermore, some of the emerging trends in China's food sectors could become big challenges for Vietnam. First, as the biggest rice producer and consumer in the world, China's embrace of GM food technologies could have major implications on the rice sector of Vietnam. Next, as China is determined to expand its fishery sector to meet the country's rising demand for food, competition between China and Vietnam over the limited fishery resources from the disputed waters in the South China Sea could intensify. Furthermore, some of the bad practices, such as the overuse of fertilizers and pesticides, and illegal additives in China's food sectors could also be replicated in Vietnam either through Chinese agricultural investors, farmers, or agricultural laborers at the border regions who frequently cross the national borders as agricultural traders or labors. Last, if China takes tougher action against counterfeited and substandard food products within its borders, some of these products could be exported or smuggled to Vietnam via the land borders, posing safety threats to local consumers, given the lax control over the cross-border trade.

\section{Notes}

1. In this article Brown argued that China's rising food inputs will put unbearable strain on the global grain export capacity, push up worldwide prices of nearly all major commodities, and make food expensive for everyone.

2. $\mathrm{RMB}$ is converted in this chapter using the exchange rate as of December 31, 2015, when USD 1 was traded at RMB 6.5. 
3. "Gutter oil" is a term used in mainland China, Hong Kong, Macao, and Taiwan to describe illicit cooking oil which has been recycled from waste oil collected from sources such as restaurant fryers, grease traps, slaughterhouse waste, and sewage from sewer drains.

4. Due to geopolitical reasons, in Vietnam it is called the "East Sea" (Biến Đông).

\section{References}

An, Hong, 2016. Chinese chemicals flood Vietnam's agricultural sector. [Online] Available at: http://e.vnexpress.net/news/news/chinese-chemicals-flood-vietnam-s-agricultural-sector-3472977.html [Accessed 20 August 2017].

Baird, I.G., Barney, K., 2017. The political ecology of cross-sectoral cumulative impacts: modern landscapes, large hydropower dams and industrial tree plantations in Laos and Cambodia. The Journal of Peasant Studies 44, 769-795. doi:https://doi.org/10.1080/03066150.2017.1289921

BBC, 2014. Report: One fifth of China's soil contaminated. [Online] Available at: http://www.bbc.com/news/world-asia-china-27076645 [Accessed 23 December 2016].

Beijing Times, 2015. 鱼类资源不足峰值 1/10渤海污染严重亟待防治 [Fish stock below 10\% of the peak level, pollution in Bohai must be addressed]. [Online] Available at: http://epaper.jinghua.cn/html/2015-03/11/content_176274.htm [Accessed 23 December 2016].

Bloomberg News, 2016. Smuggling Crackdown Seen Spurring China Sugar Reserve Sales. [Online] Available at: https:/www.bloomberg.com/news/articles/2016-09-14/smuggling-crackdown-seen-spurring-china-sugar-reservesales [Accessed 24 December 2016].

Brown, L.R., Halweil, B., 1998. China's water shortage could shake world food security. World Watch 11, 10-21.

Bureau of Fisheries of Ministry of Agriculture, P.R China, 1986. China Fishery Statistical Yearbook 1985. Beijing: China Agricultural Press.

Bureau of Fisheries of Ministry of Agriculture, P.R China, 2003. China Fishery Statistical Yearbook 2002. Beijing: China Agricultural Press.

Cai, L., Pongrace, A., Butts, C., Wang, S., 2015. China's Astounding Appetite for Pork: Recent Trends and Implications for International Trade. Penn Wharton Public Policy Initative. URL http://publicpolicy.wharton.upenn. edu/live/news/644-chinas-astounding-appetite-for-pork-recent-trends (Accessed 31 December 2017). 
Center for Coordination and Innovation of Food Safety Governance, 2014. Food Safety Governance, Beijing: Renmin University of China.

Chan, M., 2013. Xis fishermen visit seen as warning to South China Sea neighbours. URL http://www.scmp.com/news/china/article/1211086/xi-jinpingpledges-makes-seas-safer-fishermen (accessed 23 April 2016).

Chen, X., 2017. 今日头条|陈锡文:不加强农业国际竞争力农民生存空间 会越来越小The Paper. URL http://www.thepaper.cn/newsDetail_forward_1806853 (accessed 10 October 2017).

Cheng, G. \& Zhang, H., 2014. China's Global Agricultural Strategy: An Open System to Safeguard the Country's Food Security, Singapore: RSIS.

Chheang, V., 2017. The Political Economy of Chinese Investment in Cambodia (Trends in Southeast Asia), Trends in Southeast Asia. ISEAS - Yusof Ishak Institute, Singapore.

FAO - Food and Agriculture Organization, 2016. China's view on implementation and performance of agroecology, Rome: FAO.

Financial Times, 2008. UN warns of food 'neo-colonialism'. Financial. Times. URL https://www.ft.com/content/3d3ede92-6e02-11dd-b5df-0000779fd18c (Accessed 17 October 2017).

Forum Fisheries Agency, 2017. "Rai Balang Surveillance Sweep Nabs IUU Fishers: Blue Boats Spotted in PNG EEZ", 17 March 2017, available at http://www.ffa.int/node/1905 [Accessed 23 December 2016].

Forum on Health, Environment and Development (FORHEAD), 2014. Food Safety In China: A Mapping Of Problems, Governance and Research, New York, United States: Social Science Research Council (SSRC).

Fox, J., Castella, J.-C., 2013. Expansion of Rubber (Hevea brasiliensis) in Mainland Southeast Asia: What are the Prospects for Small Holders? The Journal of Peasant Studies 40(1), 155-170. doi:https://doi.org/10.1080/030 66150.2012.750605

Gale, F., 2017. China's Pork Imports Rise Along with Production Costs, Washington DC: USDA.

General Administration of Customs of China, 2014. 粮食走私危及国内食品 安全. Gen. Adm. Cust. China. URL http://www.customs.gov.cn/publish/ portal0/tab68121/info715322.htm (accessed 11.5.17).

Goldenberg, S., 2015. Lester Brown: "Vast dust bowls threaten tens of millions with hunger." The Guardian.

GrainNews, 2015. 我国成“大米走私”重灾区 [China Rice Smuggling Pervasive]. [Online] Available at: http://www.grainnews.com.cn/a/news/2015/07/1324721.html [Accessed 23 December 2016]. 
Greenpeace, 2015. Africa's Fisheries' paradise at a Crossroad: Investigating Chinese Companies, Amsterdam: Greenpeace.

Han, J., 2014. China: Food Security and Agricultural Going Out Strategy Research. Beijing: Development Press.

Hofman, I., Ho, P., 2012. China's "Developmental Outsourcing": A critical examination of Chinese global "land grabs" discourse. The Journal of Peasant Studies 39, 1-48. https://doi.org/10.1080/03066150.2011.653109

Larson, C., 2014. China's Polluted Soil Is Tainting the Country's Food Supply. [Online] Available at: https://www.bloomberg.com/news/articles/201412-08/china-s-polluted-soil-is-tainting-the-countrys-food-supply [Accessed 23 December 2016].

Le, Minh Tri., 2016. Offshore fishing and Vietnam's sovereignty protection. [Online] Available at: http://english.vietnamnet.vn/fms/marine-sovereignty/165364/ offshore-fishing-and-vietnam-s-sovereignty-protection.html [Accessed 23 December 2016].

Li，X., 2015. 中国粮食收购:肥了国企,坑了全民 [China's Grain Purchase: Benefits the State-owned grain companies but hurt the people]. [Online] Available at: http://www.chinagrain.cn/liangyou/2015/7/7/2015779425929934. shtml [Accessed 21 December 2016].

Lien, Hoang, 2015. Vietnam Debates GMO Crops With Eye on History [WWW Document]. VOA. URL https://www.voanews.com/a/vietnamdebates-gmo-crops-with-eye-on-history/2917662.html (accessed 11.5.17).

Lockett, H., 2016. Beijing taps emergency pork reserves as prices hit record high. [Online] Available at: https://www.ft.com/content/cb86e098-e495-3deb890b-5cc783d157e5 [Accessed 23 December 2016].

Lu, J., Schönweger, O., 2017. Great expectations: Chinese investment in Laos and the myth of empty land. Territory, Politics, Government (forthcoming), 1-18. doi:https://doi.org/10.1080/21622671.2017.1360195.

Mallory, T. G., 2013. China’s Distant Water Fishing Industry: Evolving Policies and Implications. Marine Policy, Volume 38, pp. 99-108.

Ministry of Agriculture, P.R. China, 2015. China Agricultural Trade Development Report, Beijing: Ministry of Agriculture, P.R. China.

Ministry of Agriculture, P.R. China, 2017. China's Number 1 Document in 2017. [Online] Available at: http://www.moa.gov.cn/ztzl/yhwj2017/zywj/201702/ t20170206_5468567.htm [Accessed 12 February 2017].

Ministry of Commerce, P.R. China, 2002-2016. China Monthly Imports and Exports Statistical Report-Agricultural Products, Beijing: Ministry of Commerce, P.R. China. 
Ministry of Commerce, P.R. China, 2016. Report on China's Outward Investment and Economic Cooperation 2016. Ministry of Commerce, P.R. China, Beijing.

Minter, A., 2016. China's Progress Is Killing the Instant Noodle. [Online] Available at: https://www.bloomberg.com/view/articles/2016-09-29/china-s-progressis-killing-the-instant-noodle [Accessed 20 August 2017].

National Bureau of Statistics, P.R. China, 2017. 2017 China Statistical Abstract. Beijing: China Statistics Press.

National Development and Reform Commission, P.R. China, 2016. National Rural Economic Development 13th Five Year Plan, Beijing, China: National Development and Reform Commission, P.R. China.

Pham, Thai Ha, 2017. Country Report: Seed Industry in Vietnam. [Online] Available at: http://www.kosaseed.or.kr/Vietnam.pdf [Accessed 23 December 2016].

Pomeroy, R., 2010. Addressing Overcapacity in the Small-Scale Marine Fisheries of Vietnam, Malaysia: WorldFish Center.

Pomeroy, R., Kim Anh Thi Nguyen \& Thong, H. X., 2009. Small-scale marine fisheries policy in Vietnam. Marine Policy, Volume 33, p. 419-428.

Qureshi, A., 2008. Food Security in China. [Online] Available at: http://hir.harvard.edu/article/?a=1750 [Accessed 23 July 2017].

Ren, Z., 2015. Solving China's Food Problem is the Top Priority of the Government. Qiushi Journal, Volume 9.

Schoenberger, L., 2017. Struggling against excuses: winning back land in Cambodia. The Journal of Peasant Studies 44, 870-890. doi:https://doi.org/1 0.1080/03066150.2017.1327850

State Council, P.R. China, 1996. The Grain Issue in China. China.org. URL http://www.china.org.cn/e-white/grainissue/index.htm [Accessed 23 July 2016].

State Council, P.R. China, 2008. China Mid-long Term Grain Security Plan (2008-2020). State Council, P.R. China, Beijing.

Straits Times, 2016. Vietnam says China 'sank' fishing boat in South China Sea. [Online] Available at: http://www.straitstimes.com/asia/east-asia/vietnamsays-china-sank-fishing-boat-in-south-china-sea [Accessed 23 July 2016].

Tang, F., 2016. Depletion of Fishery Resources along China's Coast. Cultural Geography, Volume 9, pp. 41-49.

Thuy, Thanh, 2012. Vietnamese markets flooded with cancer-causing food from China. [Online] Available at: http://www.asianews.it/news-en/Vietnamesemarkets-flooded-with-cancer-causing-food-from-China-25678.html [Accessed 20 August 2017]. 
Trade Promotion Center of the Ministry of Agriculture, P.R. China, 2016. Food Security and Non-Necessity Import Control Study. Issues in Agricultural Economy, Volume 7, pp. 53-59.

Van, Yen, 2017. President Tran Dai Quang active in China. En-Cdnqdndvn. URL http://en-cdn.qdnd.vn/foreign-affairs/bilateral-relations/president-trandai-quang-active-in-china-480851 (accessed 11.5.17).

Vietnam Business Forum, 2014. Identifying Opportunities, Challenges of Agroprocessing Industry. Vietnam Business Forum. URL http://vccinews.com/ news_detail.asp?news_id=31542 (Accessed 31 December 2017).

Viet Nam News, 2017. Agriculture need more investments and technology, say experts. [Online] Available at: http://vietnamnews.vn/economy/349898/agriculture-need-more-investments-and-technology-say-experts. html\#6PwgFh4HbmmQ3iJW.97 [Accessed 23 July 2017].

VietNamNet Bridge, 2016a. How unsafe food reaches Vietnamese's dining-table? [Online] Available at: http://english.vietnamnet.vn/fms/special-reports/ 149451/how-unsafe-food-reaches-vietnamese-s-dining-table-.html [Accessed 23 December 2016].

VietNamNet Bridge, 2016b. Why is unsafe food rampant in Vietnam? [Online] Available at: http://english.vietnamnet.vn/fms/special-reports/155277/whyis-unsafe-food-rampant-in-vietnam-.html [Accessed 23 December 2016].

VietnamNet, 2017. President attends Vietnam-China economic, trade cooperation seminar. [Online] Available at: http://english.vietnamnet.vn/fms/business/178246/president-attends-vietnam-china-economic\%2D\%2Dtradecooperation-seminar.html [Accessed 20 August 2017].

Vietnamnet, 2017a. China emerges as Vietnam's largest fragrant rice importer. [Online] Available at: http://english.vietnamnet.vn/fms/business/178656/ china-emerges-as-vietnam-s-largest-fragrant-rice-importer.html [Accessed 20 August 2017].

Vietnamnet, 2017b. China emerges as biggest importer of Vietnam tra fish. [Online] Available at: http://english.vietnamnet.vn/fms/business/177959/ china-emerges-as-biggest-importer-of-vietnam-tra-fish.html [Accessed 20 August 2017].

Vietrade, 2016. Rice export of Vietnam: successful achivements in the first 6 months of 2016. Vietrade. URL http://en.vietrade.gov.vn/index. php?option=com_content\&view=article\&id=2531:rice-export-of-vietnamsuccessful-achivements-in-the-first-6-months-of-2016\&catid=270:vietnamindustry-news\&Itemid=363 (accessed 11.5.17).

Wildau, G. \& Mitchell, T., 2016. China income inequality among world's worst. [Online] Available at: https://www.ft.com/content/3c521faa-baa6-11e5a7cc-280dfe875e28 [Accessed 23 December 2016]. 
Woods, K., 2014. Foreign Investment in Agriculture in Myanmar: FDI, Stakeholders Mapping and National Legal and Policy Assessment, Hong Kong: Oxfam.

Wu, F., Zhang, H., 2016. China’s Global Quest for Resources: Energy, Food and Water. Routledge.

Xie, Y. \& Jin, Y., 2015. Household Wealth in China. Chinese Sociological Review, 47(3), pp. 203-229.

Youchi, K., 2016. 3 great forces changing China's consumer market. [Online] Available at: https://www.weforum.org/agenda/2016/01/3-great-forceschanging-chinas-consumer-market/ [Accessed 23 December 2016].

Yu, E., 2015. China's latest stomach-churning food scandal: Frozen meat from the 1970s. [Online] Available at: http://edition.cnn.com/2015/06/24/asia/ china-smuggled-meat/ [Accessed 23 December 2016].

Zha, D. \& Zhang, H., 2013. Food in China's International relations. Pacific Review, Volume 26, pp. 455-479.

Zhang, Q.F., 2012. The Political Economy of Contract Farming in China's Agrarian Transition. J. Agrar. Change 12, 460-483. doi:https://doi. org/10.1111/j.1471-0366.2012.00352.x

Zhang, H., 2016a. China's Global Food Quest. [Online] Available at: http://thediplomat.com/2016/03/chinas-global-food-quest/ [Accessed 23 December 2016].

Zhang, H., 2016b. Chinese fishermen in disputed waters: Not quite a "people's war". Marine Policy, 68(c), pp. 65-73.

Zhang, H., 2016c. IPP REVIEW - The GMO Controversy in China: More than Food Security. IPP Rev. http://ippreview.com/index.php/Home/Blog/ single/id/70.html (accessed 11.5.17).

Zhang, H. \& Cheng, G., 2016. China's food security strategy reform: an emerging global agricultural policy. In: F. Wu \& H. Zhang, eds. China's Global Quest for Resources: Energy, Food and Water edited by Fengshi Wu and Hongzhou Zhang (Routledge, 2016). London: Routledge.

Zhao, T., 2015. China, Vietnam see booming trade in agricultural products. [Online] Available at: http://www.chinadaily.com.cn/business/2015-11/05/ content_22376636.htm [Accessed 15 August 2017]. 
Open Access This chapter is licensed under the terms of the Creative Commons Attribution 4.0 International License (http://creativecommons.org/licenses/ by/4.0/), which permits use, sharing, adaptation, distribution and reproduction in any medium or format, as long as you give appropriate credit to the original author(s) and the source, provide a link to the Creative Commons licence and indicate if changes were made.

The images or other third party material in this chapter are included in the chapter's Creative Commons licence, unless indicated otherwise in a credit line to the material. If material is not included in the chapter's Creative Commons licence and your intended use is not permitted by statutory regulation or exceeds the permitted use, you will need to obtain permission directly from the copyright holder.

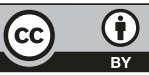

